\title{
Famous women yearn for Putin, and other unlikely tales: Glamorizing right-wing populist actors in the Bulgarian editions of Cosmopolitan and Elle
}

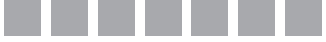 \\ Miglena Sternadori \\ ORCID: 0000-0002-4506-3625 \\ TEXAS TECH UNIVERSITY, USA
}

DOI: $10.19195 / 1899-5101.12 .2(23) .7$

\begin{abstract}
This analysis identifies the dominant media frames in the coverage of four right-wing populist actors - Vladimir Putin, Donald Trump, Silvio Berlusconi, and Roman Abramovich — by the Bulgarian editions of Elle and Cosmopolitan. Although the political platforms of these men are not, in fact, anti-establishment, which is the core characteristic of populism, they are referred to as populist actors because of their use of populist tools and discourses to practice so-called "neo-populism from above." The four men were framed as: (a) carriers of a "golden touch"; (b) sources of profound/ problematic wisdom; and (c) admirable collectors of "trophy" women. The findings are discussed as illustrative of the tabloidization of U.S. women's magazine brands in the post-communist context of Bulgaria.
\end{abstract}

KEYWORDS: women's magazines, post-communist media, right-wing populist actors, celebritization, populism.

\section{INTRODUCTION}

A low-resolution photograph on the Bulgarian website of Elle magazine shows a dark-haired woman making the peace sign. Her face is artfully contoured, and her oversized t-shirt features the angular face of a pale man, with two loaded guns crossed over his chest. The woman, Natalia Gurkova, is a former Miss Bulgaria and an Instagram celebrity. The man is Russia's president. The photo bears this caption: "To the image of Vladimir Putin on her new t-shirt, the beauty adds this quote by him: 'It doesn't matter what people say behind your back; it matters that they fall silent when you turn around"' ("Natalia Gurkova," 2018). 
The digital archives of Bulgarian Elle and Cosmopolitan, two of the most prominent Western women's magazines in the country as of $2018,{ }^{1}$ contain many more headlines about the greatness of Putin as well as the Russian oligarch Roman Abramovich, the Italian politician Silvio Berlusconi, and the U.S. president Donald Trump. Other politicians have been treated less favorably. Bulgaria's three-time prime-minister Boiko Borisov, a center-right politician, is mentioned in two stories from Elle.bg and nine from Cosmopolitan.bg, but his name has never appeared in a headline. Germany's four-term chancellor Angela Merkel, a leftist politician, is mentioned in one story from Cosmopolitan.bg and six from Elle.bg. Her name appears in only one headline, about a cartoon drawn by the fashion designer Karl Lagerfeld, a critic of hers, which depicted her next to Hitler (Voskanian, 2017). By contrast, the leftist French president Emmanuel Macron and his wife Brigitte Trogneux-Macron are the subjects of over two dozen headlines. However, their prominence is tempered by these stories' focus on looks and missteps: he cannot replace Justin Trudeau as the sexiest G7 leader; she is 24 years older; she wore a new color; the Macrons spent 26,000 euro on makeup; sent the wrong wedding gift, etc.

Why would two women's magazines practice selectively positive attention to some political figures while depicting others in an ambivalent or negative light, if at all? Although only magazine staff could fully answer this question, Putin, Berlusconi, Abramovich, and Trump share some commonalities. First, Putin is or has been friendly with the others. Second, all are current or former right-wing politicians who have used populist tools. This paper will refer to them as "right-wing populist actors," a term not to be equated to "populist politicians." The distinction is needed because the political platforms of these players are not, in fact, anti-establishment, which is the core characteristic of populism (Kazin, 2016; Lassila, 2016).

Scholars have documented patterns in the coverage of populist actors in their own countries (Koopmans \& Muis, 2009) and in the uses of social media to spread populist messages (Groshek \& Koc-Michalska, 2017). Research on populist actors' coverage by lifestyle magazines or coverage that extends across borders is, however, non-existent. This study aims to fill the gap by investigating how non-local right-wing populist actors are framed in the Bulgarian editions of two Western women's magazines.

\section{BACKGROUND}

Populism cherishes the so-called simple people, condemns intellectual elites, prefers common sense over complexity, and reveres a "unique national character that should be revived to awaken a sense of belonging and moral unity" (Krämer, 2014,

${ }^{1}$ Hearst Publishing owns the Cosmopolitan (64 international editions) and Elle (45 international editions) franchises. The Bulgarian editions are published by SBB Media (managed by the media mogul Dimitar Drumev), which also publishes the Bulgarian editions of National Geographic, Harper's Bazaar, and Men's Health (Antonova, 2016). SBB Media was created after the Finnish SanomaWSOY Group bought half of the Bulgarian company Bliasak Media ("Cosmopolitan makes debut," 2004). 
p. 43). The justification for describing Putin, Trump, Berlusconi, and Abramovich as "populist actors" lies in the practice of "neo-populism from above," which refers to "populist policies employed [...] for the purpose of preserving power and enlarging support" (Shafir, 2008, p. 425). Putin, Trump, and Berlusconi have been already described by Western scholars as right-wing populists (e.g., Fenster, 2017). Abramovich arguably fits this category as well. A former Putin political appointee (Turovskii, 2010) and sponsor of Russia's TsSKa football team, he owns the Premier League football club Chelsea, thus enabling the Russian government's use of football's "populist value" and helping Putin "gain a popular platform in a Western liberal democracy" (Veth, 2014, p. 69). Some additional relevant facts are summarized below:

- The autocratic Putin, a member of the former Soviet elite and cementer of Russia's post-communist bureaucracy, gained popularity by "wielding the tools of populism - high levels of social spending and consistent redistributionist policies" (Dimitrov, 2009, pp. 78-79).

- Roman Abramovich, former governor of Russia's far-east Chukotka region, who retains political clout because of his closeness to Putin, gained popularity by sending poor children on vacation, rebuilding infrastructure, and paying state employees on time - moves that have had an "electrifying effect on the electorate" (Midgley \& Hutchins, 2015, p. 75).

- Berlusconi, Putin's "ambassador" and "advocate" in Europe (Van Herpen, 2013, p. 183), is a media mogul and a member of the Italian elite who has led Forza Italia by appealing "to the common sense and wisdom of the Italian people" (Ruzza \& Fella, 2011, p. 166).

- Donald Trump, a self-proclaimed billionaire who has spoken warmly of $\mathrm{Pu}$ tin (Lyons, 2018), won the U.S. presidency in 2016 by using nationalistic and machismo appeals to the economic and cultural insecurities of large swathes of the population (Kazin, 2016, p. 17).

Coverage of populist actors, even when meant to entertain, offers them "discursive opportunities" and a path to public support (Koopmans \& Muis, 2009, p. 643). In an analysis of populist discourses in Norwegian women's magazines, Ytre-Anne (2011) argues that "magazine journalism can be directly relevant to public opinion" (pp. 252-253). Although the audiences of the magazines analyzed here do not determine the political fates of the likes of Putin and Berlusconi, their attitudes are transferrable to local politicians who obtain endorsements from these or other wellknown populist actors. As Koopmans and Muis suggest, "[t]he success or failure of populist right parties throughout Europe [...] depends as much, or more, on the actions and reactions of other political and media actors than on the personality, skills, and tactics of populist political entrepreneurs" (p. 660; emphasis mine). 


\section{LITERATURE REVIEW}

This section outlines the literature on media and populism by discussing magazines' role in disseminating populist messages, women's magazines' foray into politics, populism in East Central Europe, and the socio-political landscape of Bulgaria, a former Soviet satellite.

\section{Media and populist actors}

Cross-cultural news values, including conflict and the focus on narratives that "defy the existing order" (Mazzoleni, Stewart, \& Horsfield, 2003, p. 7), often contribute to the success of populist actors who claim to fight the establishment or use fear discourses - about immigrants, minorities, non-traditional families, etc. (Wodak, 2015). In most of the West, populist discourses have traditionally been spread by talk radio, tabloids, and infotainment TV (Krämer, 2014). In post-communist and other contexts, however, populism has penetrated the "elite" media, such as national newspapers, in an all-encompassing process of "tabloidization" (Mazzoleni et al., 2003, p. 9). Thanks to unregulated digital platforms, which can spread misinformation and discourses of rage (Freedman, 2018), populist discourses in media content have influenced recent political developments in the Philippines (McCargo, 2016), Pakistan (Mulla, 2017), Turkey (Bulut \& Yörük, 2017), and India (Chakravartty \& Roy, 2016).

\section{Magazines and populism}

One characteristic of the magazine form is that it "lends itself to opinionated expression" (Forster, 2015, p. 1), as illustrated by various magazines serving as "official organs or newsletters to promote oppositional political ideas" (p. 5). Haveman (2004) confirms that " $[\mathrm{m}]$ agazines promote discourses - principles, symbols, and ideas - that social groups use to deal with social problems" (p. 24). At the cusp of the 20th century, several magazines represented the views of the U.S. Populist Party: Southern Arena in Texas (Pool \& Cureton, 1977), the Boston-based Arena (McConnaughy, 2013), and Watson's Jeffersonian in Georgia (Woodward, 1938). About the same time in pre-Soviet Russia, the reformist populist magazine Russian Wealth (Русское Богатство) upset the status quo by publishing articles about political freedoms (Blokhin \& Soloviev, 2017).

Unsurprisingly, present-day populist parties continue to rely on the magazine form. In Germany, the right-wing populist periodical Compact (https://www.compact-online.de/), edited by the activist Jürgen Elsässer, supports Putin's policies and vilifies German chancellor Angela Merkel (Simpson, 2016). Other examples include UK's Vox Populist, a "voice for the populist alliance" (Vox Populist, n.d.); the French Identité, published by the right-wing Front National (Zúquete, 2008); and 
Hungary’s Barikad (Bar!kad), a "bombastic newsweekly" (Krausz, 2017) published by Jobbik, the right-wing Movement for a Better Hungary, until 2017.

\section{Politics and women's magazines}

Although " $[\mathrm{w}]$ omen's magazines are generally not associated with the forms of journalism which bring citizens information of crucial democratic importance" (YtreArne, 2011, p. 247), this changed in the U.S. in the 1970s with the emergence of progressive magazines, such as Ms and Mother Jones, which aligned with the social justice movement. Since the 1970s, mainstream women's magazines have also introduced political coverage, publishing articles about the Equal Rights Amendment (ERA), welfare, abortion, violence against women, and feminism (Sternadori \& Hagseth, 2014). Unsurprisingly, U.S. right-wing entities view women's magazines as Trojan horses for liberalism. Phyllis Schlafly, "the mother of right-wing populism" (Critchlow, 2016, n.p.), who campaigned against the proposed constitutional amendment guaranteeing gender equality, repeatedly criticized women's magazines for supporting the ERA (Solomon, 1983). In the 1990s, a U.S. conservative thinktank called women's magazines "a liberal pipeline to soccer moms" (Media Research Center, 1996).

Progressivism in women's magazine content has been noted across the world. In Finland, "interviews in women's magazines are an important component of the public performance of top female politicians today" as these periodicals espouse feminist ideals (Saarenmaa \& Ruoho, 2014, p. 290). In Turkey, women's magazines launched in the 1980s covered women's underrepresentation in politics alongside depictions of traditional femininity (Kirca, 2001). Cosmopolitan's edition in Taiwan offered progressive discourses about sexual harassment and pay equity even as its editors and readers viewed Western feminism as "radical" and irrelevant (Chang, 2004). In Russia’s $G Q$ and Cosmopolitan, progressive and anti-Putin themes coexist with gender stereotypes (Levintova, 2013). But even though women's magazines sometimes offer anti-establishment discourses - especially ones challenging the patriarchal status quo - they are not known for coverage of right-wing populist actors, who are the subject of this article.

\section{Post-communist media and populism}

Shafir (2008) writes that the seeds of East Central Europe's right-wing populism (a term he contests because of its conceptual vagueness) were sown by the region's communist past, causing distrust of large-scale systems and the word "party," which used to refer singularly to the (Communist) Party. As post-1989 rises in inequality, organized crime, and economic uncertainty fostered the disillusionment of voters who had envisioned market economy bliss, the region offered a fertile ground for nationalist and populist appeals (Mudde, 2000). "Democracy fatigue" and the lack 
of "truly independent media to serve as a counterweight to creeping authoritarianism" further fuelled the region's rise of right-wing populism (Rupnik, 2007, p. 24).

This trend was recently compounded by the so-called "refugee crisis" (Mudde, 2017), in which "press coverage that promoted hate speech and hostility towards migrants was systematic and persistent in a proportion of the press" (Georgiou \& Zaborowski, 2017, p. 3). Illustrating this concern, a Hungarian camerawoman was caught on film tripping refugees and kicking a child (Mackintosh, 2017). The hateful opposition to refugees contributed to the backsliding of early EU admittees, such as Hungary and Poland, into right-wing political discourses emphasizing authoritarian agendas (Krzyżanowski, Triandafyllidou, \& Wodak, 2018).

Like the rest of the region, Bulgaria has since 1989 seen increasing political polarization and fluctuating economic growth. Its media market grew quickly from two TV channels and seven national dailies in 1989 to include hundreds of newspapers and radio and TV channels, many of which have been short-lived (Tabakova, 2008). The country's 2007 admission into the European Union did nothing to discourage, and may have even encouraged, the rise of nationalist and authoritarian rhetoric (Cholova \& De Waele, 2011; Gurov \& Zankina, 2013). Such rhetoric has now become the norm. In the Bulgarian National Television's 2015 pre-election coverage, all politicians used "soft" populism discourses (identifying with the people and colloquial speech), and the far-right nationalist parties also used "hard" populism, such as hostile statements about immigrants and minorities (Peicheva \& Raycheva, 2017). The entry of global media brands, including magazine franchises, appears to have done little to change the country's culture. This is not surprising because, as Hofstede, Hofstede and Minkov (2010) note, "[g]lobalization by multinational corporations [...] meets fierce local resistance because economic systems are not culture free" (p. 24). Based on this literature, the following question is posed: RQ1: What media frames do the Bulgarian editions of Western women's magazines use in articles about right-wing populist actors?

\section{METHOD}

This article employs a media framing analysis, which discerns "causal interpretations, moral evaluations, and treatment recommendations" in media coverage (Weaver, 2007, p. 143). This approach is relevant to the study of non-local populist actors because media frames are more likely to shape audiences' perceptions of reality about individuals and issues foreign to them (Slater, 1990).

Framing is grounded in the theory of social construction of reality, which suggests that media and other institutions create, reflect, and reinforce the mental images that people employ in their interactions with one another (Berger \& Luckmann, 1966). To political scientists, framing is "the process by which people develop a particular conceptualization of an issue or reorient their thinking about an issue" (Chong \& Druckman, 2007, p. 104). In journalism studies, framing describes the 
imposition of "artificial order on a chaotic reality" as "journalists seek culturally recognized narratives and use them as foundation stones on top of which to craft their reports" (Sternadori, 2007, p. 15).

Goffman (1974) and Entman (1993) emphasize the concept of salience as central to framing: What is excluded in a depiction or a narrative is just as important as what is included. Entman (1993) suggests that " $[\mathrm{t}] \mathrm{o}$ frame is to select some aspects of a perceived reality and make them more salient in a communicating text, in such a way as to promote a particular problem definition, causal interpretation, moral evaluation, and/or treatment recommendation" (p. 52). "Framing analysis typically takes into account (a) the main ideas of a message; (b) explicit or implicit causal statements; (c) phrases or labels that suggest flattering or unflattering attributes; and (d) ideologically influenced word choices and rhetorical structures (Bashir \& Fedorova, 2015; Gamson \& Modigliani, 1989; Pan \& Kosicki, 1993). Because there are "no uniform measurement standards" for frames (Chong \& Druckman, 2007, p. 106) and frames do not reflect "objectively identifiable meanings" (Pan \& Kosicki, 1993, p. 58), this analysis was qualitative. No coding sheet was employed. The analysis consisted of systematically reading, re-reading, and analyzing the written text of the identified articles through the subjective lens of the author's cross-cultural knowledge about socio-political realities and journalistic practices. The unit of analysis was the sentence - meaning that, in principle, all frames identified in the coverage could be present within the same article. However, that was not the case in this study.

\section{CONTENT SELECTION}

The Bulgarian editions of Elle ${ }^{2}$ and Cosmopolitan ${ }^{3}$ were selected because they represent two of the largest Western women's magazines franchises in the country (other such franchises currently present in Bulgaria include Condé Nast's fashion titles Glamour and Vogue). Their cases illustrate U.S. women's magazines' successful entry into foreign markets, thanks to the relatively easy translation and cross-cultural appeal of aspirational images and stories, light-hearted advice, and infotainment. As local editions of global franchises, Bulgarian Elle and Cosmopolitan can be expected to combine global schemas related to story ideas, layout, and visuals with local discourses (Machin \& van Leeuwen, 2003). This study used only the magazines' digital

2 The website of Elle Bulgaria, launched in 2005, indicates its current monthly print run at 16,000 and its readership 24,200. The magazine's readers are $99 \%$ women, $61 \%$ are between 26 and $45,56 \%$ live in urban areas, $74 \%$ are employed, and $90 \%$ have a secondary or university education (SBB MediaMagazines, 2018).

3 Cosmopolitan Bulgaria, launched in 2004 with a circulation of 60,000 ("Cosmopolitan makes debut," 2004), has a current estimated circulation of 36,593 and readership stands of 167,227 (Mercury Publicity, 2018). Audience surveys indicate $77 \%$ of the readers are women, $72 \%$ are under $35,80 \%$ live in urban areas, $59 \%$ are employed, and $86 \%$ have secondary or university education (Cosmopolitan Media Kit-Bulgaria, 2017). 
archives - a choice of convenience, as I did not have access to the print archives. All analyzed content was published in Bulgarian. The framing analysis was possible because as a former Bulgarian journalist, I had the requisite linguistic, cultural, and socio-political foundation for such a study. The searches included all available articles, from the launch of the Bulgarian Cosmopolitan in 2004 and Elle in 2005 through the analysis' completion in September 2018.

\section{Keyword searches}

The term "right-wing populist actors" was operationalized to include Putin, Trump, Berlusconi, and Abramovich because an initial review of the magazines' digital archives suggested they were receiving unusually celebritized coverage not afforded to other major figures of socio-political significance. Searches were conducted for the names of other well-known politicians who have been referred to in academic texts and media coverage as right-wing populist actors. These included Bulgaria's Volen Siderov (mentioned once in an Elle.bg article), Hungary’s Victor Orbán (zero headlines or mentions), the Philippines' Rodrigo Duterte (mentioned once in a Cosmopolitan.bg article), France's Marine Le Pen (mentioned in one story from Elle.bg), Britain's Nigel Farage (zero headlines or mentions) and Boris Johnson (mentioned once in a Cosmopolitan.bg article), and Turkey's Recep Tayyip Erdoğan (one mention of him and one of his wife in articles on Elle.bg). These searches indicated that, unlike Putin, Abramovich, Berlusconi, and Trump, these right-wing populist figures were never the subject of any headlines and also received fewer mentions (Table 1). To further verify that Elle and Cosmopolitan had a specific interest in Abramovich and not Russian oligarchs in general, I also searched for the names of the seven richest Russian billionaires as identified by Forbes magazine. ${ }^{4}$ These searches found no headlines or mentions of any other Russian oligarchs.

Next, I used Putin's, Trump's, Berlusconi's, and Abramovich's names as search keywords, typing their last names in Cyrillic (“Путин," “Тръмп," “Берлускони," and "Абрамович") in the search boxes of www.elle.bg and www.cosmopolitan.bg. Using only last names was intended to identify stories that referenced not only the populist actors, but also their family members. The searches on Cosmopolitan.bg found mentions both in magazine articles and the website's forums (for example, on July 17, 2006, forum user Kitty expressed hopes that Putin will "put the U.S. in its place"). The analysis included only magazine articles. The name "Trump" found the most headlines, the majority being about Donald Trump's wife, Melania Trump, and daughter Ivanka Trump. The number of articles from each magazine that were closely read in order to identify frames appear in Table 1 . Not all of the analyzed articles are directly cited in this manuscript.

\footnotetext{
${ }^{4}$ Retrieved June 13, 2019, from http://www.forbes.com/pictures/gefl45emmh/3-alisher-usmanov/\#2c4c5d9ae71b.
} 
Table 1. Number of times the four identified populist actors appear in headlines and within stories in the digital archives of Elle.bg and Cosmopolitan.bg

\begin{tabular}{|l|c|c|c|c|c|c|c|c|}
\hline & \multicolumn{2}{|c|}{ Putin } & \multicolumn{2}{c|}{ Abramovich } & \multicolumn{2}{c|}{ Berlusconi } & \multicolumn{2}{c|}{ Trump } \\
\hline & $\begin{array}{c}\text { Head- } \\
\text { lines }\end{array}$ & $\begin{array}{c}\text { Men- } \\
\text { tions }\end{array}$ & $\begin{array}{c}\text { Head- } \\
\text { lines }\end{array}$ & $\begin{array}{c}\text { Men- } \\
\text { tions }\end{array}$ & $\begin{array}{c}\text { Head- } \\
\text { lines }\end{array}$ & $\begin{array}{c}\text { Men- } \\
\text { tions }\end{array}$ & $\begin{array}{c}\text { Head- } \\
\text { lines }\end{array}$ & $\begin{array}{c}\text { Men- } \\
\text { tions }\end{array}$ \\
\hline Elle.bg & 2 & 10 & 1 & 6 & 0 & 3 & 59 & 10 \\
\hline $\begin{array}{l}\text { Cosmopoli- } \\
\text { tan.bg }\end{array}$ & 6 & 1 & 4 & 5 & 3 & 0 & 49 & 10 \\
\hline Total & 8 & 11 & 5 & 11 & 3 & 3 & 108 & 20 \\
\hline
\end{tabular}

Source: Author.

\section{FINDINGS}

The portrayals of Putin, Trump, Berlusconi, and Abramovich in the Bulgarian editions fit surprisingly well with the magazines' celebrity coverage. The four men's political histories, platforms, and beliefs were never mentioned. This approach is radically different from the modus operandi of the same magazines' home (U.S.) editions, which cover Trump and other right-wing politicians in the context of their political (in)actions, as illustrated by recent Cosmopolitan.com headlines such as "Republican lawmakers are human shrug emojis" (Filipovich, 2018) and "The intern who yelled ' $\mathrm{f}^{*} \mathrm{ck}$ you' at Trump does not regret it" (Minutaglio, 2018). The focus on past actions to contextualize current events was evident in a recent U.S. Elle story entitled "Of course no one wanted to tell Trump he had toilet paper stuck to his shoe," which opened with the following sentence: "Breaking news: a strange man who inherited a massive amount of wealth and has fallen up his entire life despite a very bad personality and a propensity for doing crimes embarrassed himself publicly" (Thomas, 2018, para. 1).

Frames in communication are "the key considerations [...] in relation to a specific issue, event, or political actor" (Chong \& Druckman, 2007, p. 106). The following common ways of seeing and thinking about the four right-wing populist actors emerged from the Bulgarian magazine editions' coverage: (a) carriers of a "golden touch"; (b) sources of profound/problematic wisdom; and (c) admirable collectors of "trophy" women. Each frame is illustrated with examples in the sections below. Only one of the frames was clearly identifiable in each article, with the exception of one in which the "golden touch" and "trophy" women frames co-existed ("Roman and Darya," 2017). Putin, Abramovich, and Berlusconi were always covered in a positive light. By contrast, some headlines about Trump highlighted popular and celebrity-sourced criticisms of the U.S. president, but did not reference any facts that explain why Trump is disliked - a major omission that appears to implicitly challenge the credibility of such criticisms. 


\section{Carriers of a "golden touch"}

In Greek mythology, the gods punish King Midas's greed by making him turn everything he touches, including his loved ones, into gold. But in the Bulgarian editions of Elle and Cosmopolitan, the "golden touch" of Putin, Trump, Berlusconi, and Abramovich is a symbolic, benevolent, and admirable side effect of their street smartness, power, and fame. The stories that represented this frame highlighted a product's or an issue's added value (not necessarily monetary) resulting from its association with one of the right-wing populist actors.

A prime example was an article about a designer lambskin jacket by the company Matchless London, reportedly created to honor Putin's standing as a modern "superhero" and released on Putin's birthday ("Vladimir Putin inspired," 2017). The jacket's value appeared to be attributed primarily to its association with Putin. Another example was a story about $\$ 29,200$ being paid at an auction for a 2005 marker-drawn image of New York's skyline - a "primitive" drawing by Trump, with his signature and some "hardly noticeable" spots (BGNES, 2017a). A third example promoted a porn parody titled "Bunga-Bunga, Presidente," featuring a lascivious prime minister similar to Berlusconi (BGNES, 2011). The story included no background on Berlusconi's real-life "bunga-bunga" parties, which had involved underage teenagers and resulted in criminal charges. The headline, "Berlusconi plays top role in porn parody," implied Berlusconi had played himself, but online information about the production did not confirm that.

In a variation of the "golden touch" frame, Elle.bg featured Roman Abramovich as a "star" alongside much more recognizable Western celebrities and entrepreneurs. Examples included an article about "the stars' private jets" (Pizhov, 2016a), which listed Abramovich alongside Harrison Ford and Tom Cruise; a story about the island of Sardinia, frequented by Bruce Willis, Denzel Washington, and Lenny Kravitz, where Abramovich owns property ("Oh, those beaches," 2015); and a story about billionaires without college degrees, which identified "Mark Zuckerberg, Roman Abramovich, Bill Gates, and other entrepreneurs" (Vangelova, 2016a, n.p.). In these cases, Abramovich's name seemed to be used to lend credibility or a sense of affinity among Bulgarian readers unfamiliar with or uninterested in Western celebrities.

\section{Sources of profound/problematic wisdom}

This frame, found only on Elle.bg, represented the assumption that people who are rich and famous - regardless of how they became so - must know something about life and success that ordinary people do not. Outside of a post-communist context, the presumably profound quotes attributed to right-wing populist actors would be perceived as problematic because they suggest that the ends (power, wealth) justify the means, including potentially unethical and illegal actions. Western women's magazine editors are also unlikely to offer their audiences quotes that are dismissive of women 
or sexual minorities, which - as will become evident in the next paragraphs - is precisely the case for the quotes used by the Bulgarian edition of Elle.

Trump, a near-genius with a reported IQ of 156 ("Star IQ test," 2017), was the source of 10 quotes published a month after he had launched his presidential campaign. The list included a statement that women were drawn to his determination rather than money, along with sage advice emphasizing outcome over process: "In the end, you're measured not by how much you undertake, but by what you accomplish" ("10 quotes," 2015, n.p.). The following year, another list featured Trump's "brightest quotes," including an undated statement suggesting women are men's property: "Even your friends are ready to stab you in the back to take your job, your home, your money, your woman, your freedom - in the end, everything" 5 (Vangelova, 2016c, n.p.). The same year, a list of 10 life tips from Abramovich (accompanied by three close-up portraits of the oligarch) emphasized situational ethics: "The vast majority of 'musts' and 'oughts' you follow are useless. All you get from them is stress and guilt. By following imaginary rules, you burden your brain with unnecessary obstacles" (Vangelova, 2016b, n.p.).

Two more examples of problematic "wisdom" illustrated this frame. One was a list of quotes about love, which led with advice from Berlusconi: "It is better to date pretty girls than to be gay!" ("Politicians and love," 2017). It is unclear why the unnamed writer or editor selected Berlusconi's homophobic and heteronormative declaration to represent "love" in 2017. The second example appeared in an undated list of "unforgettable" quotes that politicians "may have regretted." In it, Putin expressed admiration for Israel's president Moshe Katsav, at the time accused of sexual assault, while speaking to Israel's prime-minister: "Say hi to your president. He turned out to be a strong man! Raped 10 women! I never would have expected it of him. He has surprised us all. We all envy him" ("11 statements," 2016). According to The Guardian, this quote was recorded in 2006 and was declared a joke by a Kremlin spokesperson (Parfitt, 2006).

\section{Admirable collectors of "trophy" women}

References to attractive women appeared to be used to legitimize the power and fame of the right-wing populist actors identified in this analysis. Putin's success with women was a frequent topic, including an article suggesting a relationship between Putin and actress Wendy Deng ("Rupert Murdoch's ex," 2017) and other headlines implying famous women's attraction to Putin. One misleading headline claimed the Italian actress Ornella Muti had been convicted for dining with Putin. The story clarified that Muti's conviction was for fraud: she had avoided a theater performance by claiming to be sick while attending a St. Petersburg fundraiser, where Putin was present ("Ornella Muti," 2015). Under another misleading headline, "Lindsey Lohan going nuts — wants

5 An English-language Google search using a variation of keywords could not verify the existence of any statements by Trump that resembled this quote. 
Russian President Putin," Cosmopolitan.bg reported on a Russian talk show's offer to Lohan to make a guest appearance and on Lohan's "demands": a Russian visa, security detail, a makeup artist, a stylist, and a photo op with Putin ("Lindsey Lohan," 2016).

Berlusconi's appeal to women was the subject of two articles. One, about Berlusconi's divorce from the actress Veronica Lario, mentioned twice that his new girlfriend, Francesca Pascale, 50 years his junior, wanted to marry him (BGNES, 2017b). Another story reported that Berlusconi's former secretary had left him 3 million euro after her death (BGNES, 2018). Although the article did not suggest the woman had been in love with Berlusconi, the headline implied a common female-secretary-male-boss-affair trope.

Trump's "trophy" frame included coverage of Melania Trump, his third wife, emphasizing her appearance and sex appeal. Shortly before the 2016 U.S. presidential election, Elle.bg cited an unattributed public poll suggesting she would be considered the sexiest first lady if Trump is elected ("5 facts," 2016). Described as a "beautiful Slovenian" and a "beautiful brunette" (Kusmetska, 2016, n.p.), she was highlighted for her ordinary roots - "one of millions of immigrant women in the U.S." ("Donald Trump," 2016). But because of her marriage to Trump, she was also framed as a rankable complement to his status: "Media outlets have shared more than once that if Mrs. Trump enters the White House, she would surely be the sexiest first lady" ("Donald Trump," 2016). To prove the point, two days after Trump's election Elle.bg ran an undated photo of a naked Melania Trump - her hand in front of her pubic area and her nipples blurred - claiming that her "modeling past overshadowed the appearances of the newly-elected president in media and social networks" (Pizhov, 2016b, n.p.).

In a slightly different twist of the "trophy" woman frame, articles about former model Darya Zhukova, the third wife of Roman Abramovich, emphasized the benefits of having a wealthy husband. Zhukova was highlighted for her worldliness, backed up by her husband's riches: founding a museum of modern art in Moscow ("Billionaire's wife," 2015) and attending a Monaco royal wedding ("Another royal," 2015). When she and Abramovich separated, Cosmopolitan.bg framed the event as a boon for Zhukova by chronicling Abramovich's previous divorce, in which his ex-wife received millions of dollars (“Roman and Darya," 2017).

\section{DISCUSSION}

The goal of this study was to explore the dominant frames in the coverage of rightwing populist actors (Vladimir Putin, Donald Trump, Silvio Berlusconi, and Roman Abramovich) by the websites of the Bulgarian editions of Elle and Cosmopolitan. The three identified frames in the men's depictions - carriers of a "golden touch," sources of allegedly profound but problematic wisdom, and successful collectors of "trophy" women - suggest that these populist actors were glamorized in ways that would be unacceptable in Western women's magazines, including the home editions of Elle and Cosmopolitan. 
Many of the analyzed articles were unsourced and lacked attribution, which made verifying their content from other sources difficult or impossible. Some explicitly objectified women or included egregious errors of omission and context. For example, an Elle.bg story claiming that, as of November 10, 2016, "Melania Trump's modeling past overshadowed the appearances of the newly-elected president in media and social networks" (Pizhov, 2016b, n.p.) was blatantly inaccurate because at that time most U.S. and most Western media were grappling with the unexpected election result and attempting to predict the future (e.g., Tsang, 2016).

The findings illustrate the populist-style tabloidization of global magazine brands in a post-communist context. Although Elle's and Cosmopolitan's Bulgarian editions do not convey any political messages, their portrayal of right-wing populist actors as down-to-earth celebrities, yet on par with famous Western singers and actors, indirectly supports local politicians who align with them. The populist actors are portrayed as having some shortcomings - Abramovich lacks a college degree, Putin said something he may regret, Berlusconi lacks sexual impulse control, and Trump has no talent for drawing. However, such considerations could be considered weak "competing frames," which do not challenge and may even reinforce the credibility of the main identified frames (Chong \& Druckman, 2007, p. 112).

\section{THEORETICAL AND PRACTICAL IMPLICATIONS}

This study contributes to the literature on media and populism by analyzing the coverage of right-wing populist actors by Western women's magazines in a postcommunist context. The findings suggest that the Bulgarian editions of Elle and Cosmopolitan rely on simplistic, sensationalized discourses that cast controversial figures such as Putin, Trump, Berlusconi, and Abramovich as folk heroes, employing "schemata that are as close as possible to the assumed knowledge" of the audience (Krämer, 2014, p. 49).

The findings support Machin and van Leeuwen's (2003) argument that magazines' international editions combine global schemas and local discourses because the positive coverage of right-wing populist actors aligned with Bulgarian audiences' current support for populist messages (Peicheva \& Raycheva, 2017), while also reflecting Western individualistic schemas about the importance of personal success (Machin \& van Leeuwen, 2008). However, some of the observations that emerged during the analysis challenge Machin and van Leeuwen's (2003) notion of global media franchises' standardization of content. For example, most of the analyzed stories violated customary news-writing practices, such as attribution to sources.

The study illustrates the limited professionalization of Bulgarian journalists, who provide coverage to right-wing populist actors seemingly without any awareness of the accusations and charges against them: human-rights violations for Putin (Kasparov, 2015); sexual coercion for Trump (Ford, 2017); tax fraud for Berlusconi (“The many trials," 2014); and money laundering for Abramovich (Garside, 2018). 
For Hearst Publishing, owner of the Elle and Cosmopolitan franchises, the findings may suggest a need for a closer oversight of international editions.

\section{LIMITATIONS AND DIRECTIONS FOR FUTURE RESEARCH}

The study was limited by its focus on a single country and specifically on two global magazine brands' Bulgarian editions, which have the same publisher. It is difficult to know whether their content is representative of their publisher's associations and political views or indicates trends applicable to other women's publications in the region. Future research could compare the coverage of right-wing populist actors across Bulgarian women's periodicals as well as between Bulgarian and other post-communist editions of Elle and Cosmopolitan. The set of frames identified in this study could serve to create a coding sheet for a quantitative content analysis of populist actors' coverage by lifestyle periodicals. Finally, interviews with writers and editors of these and other magazines in post-communist countries could yield insights into the values and criteria used by magazine editors in covering populist actors.

\section{REFERENCES}

5 facts about Melania Trump. (2016, April 13). Elle.bg. Retrieved November 24, 2018, from http://www. elle.bg/istorii/5-fakta-za-melaniia-trump.html.

10 quotes about career and life by Donald Trump. (2015, August 1). Elle.bg. Retrieved November 24, 2018, from http://www.elle.bg/kariera/10-citata-za-karierata-i-jivota-ot-donald-trump.html.

11 statements by politicians that are hard to forget. (2016, November 10). Elle.bg. Retrieved November 24, 2018, from http://www.elle.bg/kariera/11-izkazvaniia-na-politici-koito-trudno-bihme-zabravili.html.

Antonova, V. (2016, January 16). Life is already “The Economist." Capital. Retrieved November 24, 2018, from https://www.capital.bg/biznes/media_i_reklama/2016/01/16/2686621_life_veche_e_ikonomist/.

Another royal wedding in Monaco. (2015, August 3). Elle.bg. Retrieved November 24, 2018, from http:// www.elle.bg/novini-35/oshte-edna-kralska-svatba-v-monako.html.

Bashir, M., \& Fedorova, M. (2015). Framing the Pussy Riot between the USA and Russia. The Journal of International Communication, 21(1), 132-152.

Berger, P., \& Luckmann, T. (1966). The social construction of reality: A treatise in the sociology of knowledge. Garden City, NY: Anchor Books.

BGNES. (2011, March 21). Berlusconi plays top role in porn parody. Cosmopolitan.bg. Retrieved November 24, 2018, from http://www.cosmopolitan.bg/po-sveta-/berluskoni-igrae-glavnata-rolya-vporno-parodiya.html.

BGNES. (2017a, July 27). \$29,200 paid for a "unique" drawing by Donald Trump. Cosmopolitan.bg. Retrieved November 24, 2018, from http://www.cosmopolitan.bg/po-sveta-/dadoha-29-200-dolara-zaunikalna-risunka-na-donald-trump.html.

BGNES. (2017b, November 17). Berlusconi’s ex must give him back 60 million euro. Cosmopoltan.bg. Retrieved November 24, 2018, from http://www.cosmopolitan.bg/zvezden-bulevard/bivshata-naberluskoni-triabva-da-mu-vurne-60-mln-evro.html.

BGNES. (2018, May 21). Former secretary of Berlusconi willed him 3 million euro. Cosmopolitan.bg. Retrieved November 24, 2018, from http://www.cosmopolitan.bg/po-sveta/bivsha-sekretarka-naberluskoni-mu-dari-3-mln-evro.html. 
Billionaire's wife opened Moscow's largest museum. (2015, June 12). Elle.bg. Retrieved November 24, 2018, from http://www.elle.bg/izlojbi/miliarderska-supruga-otkri-nai-golemiiat-muzei-v-moskva. html.

Blokhin, V. V., \& Soloviev, E. A. (2017). NK Mikhailovski and the Democratic movement in Russia in the second half of the 19th Century: Political doctrine and activity. Bilie Goda: Rossijskij Istoricheskij Jurnal, 46, 1443-1453.

Bulut, E., \& Yörük, E. (2017). Digital populism: Trolls and political polarization of Twitter in Turkey. International Journal of Communication, 11, 4039-4117.

Chakravartty, P., \& Roy, S. (2015). Mr. Modi goes to Delhi: Mediated populism and the 2014 Indian elections. Television \& New Media, 16(4), 311-322.

Chang, J. S. (2004). Refashioning womanhood in 1990s Taiwan: An analysis of the Taiwanese edition of Cosmopolitan magazine. Modern China, 30(3), 361-397.

Cholova, B., \& De Waele, J. M. (2011). Bulgaria: A fertile ground for populism? Slovak Journal of Political Science, 1, 25-54.

Chong, D., \& Druckman, J. N. (2007). Framing theory. Annual Review of Political Science, 10, 103-126.

Cosmopolitan makes debut on Bulgarian market. (2004, January 27). Novinite.com. Retrieved November 24, 2018, from http://www.novinite.com/articles/30338/Cosmopolitan+Makes+Debut+on+Bulgaria n+Market.

Cosmopolitan Media Kit-Bulgaria (2017). Retrieved November 24, 2018, from https://www.piero97.com/ wp-content/uploads/2016/11/Cosmopolitan-MediaKit-2017-EN.pdf.

Critchlow, D. T. (2016, September 8). Phyllis Schlafly, the mother of right-wing populism. The Washington Post. Retrieved November 24, 2018, from http://www.washingtonpost.com.

Dimitrov, M. K. (2009). Popular autocrats. Journal of Democracy, 20(1), 78-81.

Donald Trump brings immigrant to White House. (2016, November 10). Cosmopolitan.bg. Retrieved November 24, 2018, from http://www.cosmopolitan.bg/po-sveta/donald-trump-vkarva-emigrantkav-beliia-dom.html.

Entman, R. (1993). Framing: Toward clarification of a fractured paradigm. Journal of Communication, 43(4), 51-58.

Fenster, M. (2017). Transparency in Trump's America. Governance, 30(2), 173-175.

Filipovich, J. (2018, February 27). Republican lawmakers are human shrug emojis. Cosmopolitan.com. Retrieved November 24, 2018, from https://www.cosmopolitan.com/politics/a18754262/ republican-politicians-shrug-inaction/.

Ford, M. (2017, December 7). The 19 women who accused President Trump of sexual misconduct. The Atlantic. Retrieved November 24, 2018, from http://www.theatlantic.com.

Forster, L. (2015). Magazine movements: Women's culture, feminisms and media form. New York and London: Bloomsbury Academic.

Freedman, D. (2018). Populism and media policy failure. European Journal of Communication, 33(6), 604-618.

Gamson, W., \& Modigliani, A. (1989). Media discourse and public opinion on nuclear power: A constructionist approach. American Journal of Sociology, 95(1), 1-37.

Garside, J. (2018, September 25). Roman Abramovich posed threat to public security, Swiss police said. The Guardian. Retrieved November 24, 2018, from http://www.theguardian.com.

Georgiou, M., \& Zaborowski, R. (2017). Media coverage of the "refugee crisis": A cross-European perspective [report]. Council of Europe.

Goffman, E. (1974). Frame analysis: An essay on the organization of experience. Cambridge, MA: Harvard University Press.

Groshek, J., \& Koc-Michalska, K. (2017). Helping populism win? Social media use, filter bubbles, and support for populist presidential candidates in the 2016 US election campaign. Information, Communication \& Society, 20(9), 1389-1407. 
Gurov, B., \& Zankina, E. (2013). Populism and the construction of political charisma: Post-transition politics in Bulgaria. Problems of Post-Communism, 60(1), 3-17.

Haveman, H. A. (2004). Antebellum literary culture and the evolution of American magazines. Poetics, $32,5-28$.

Hofstede, G., Hofstede, G. J., \& Minkov, M. (2010). Cultures and organizations: Software of the mind (3rd ed.). New York: McGraw Hill.

Kasparov, G. (2015, March 6). The killing of my friend Boris Nemtsov must signal the death of appeasement. The Guardian. Retrieved November 24, 2018, from http://www.theguardian.com.

Kazin, M. (2016). Trump and American populism: Old whine, new bottles. Foreign Affairs, 95, 17.

Kirca, S. (2001). Turkish women's magazines: The popular meets the political. Women's Studies International Forum, 24(3-4), 457-468.

Koopmans, R., \& Muis, J. (2009). The rise of right-wing populist Pim Fortuyn in the Netherlands: A discursive opportunity approach. European Journal of Political Research, 48(5), 642-664.

Krämer, B. (2014). Media populism: A conceptual clarification and some theses on its effects. Communication Theory, 24(1), 42-60.

Krausz, T. (2017, February 12). A whole new Jew: The anti-Semite who turned out to be one of the Jews he despised. The Jerusalem Post. Retrieved 24 November, 2018, from http://www.jpost.com/ Jerusalem-Report/A-whole-new-Jew-478706.

Krzyżanowski, M., Triandafyllidou, A., \& Wodak, R. (2018). The mediatization and the politicization of the "refugee crisis" in Europe. Journal of Immigrant and Refugee Studies, 16(1-2), 1-14.

Kusmetska, I. (2016, June 14). Melania Trump: Hillary Clinton came to my wedding without a gift. Elle. bg. Retrieved November 24, 2018, from http://www.elle.bg/novini-35/melaniia-trump-hilari-klintundoide-na-svatbata-mi-bez-podaruk.html.

Lassila, J. (2016). Aleksei Naval'nyi and populist re-ordering of Putin's stability. Europe-Asia Studies, 68(1), $118-137$.

Levintova, E. (2013). Glamorous politics or political glamour? Content analysis of political coverage in Russian glossy magazines. Communist and Post-Communist Studies, 46(4), 503-511.

Lindsey Lohan going nuts - wants Russian president Putin. (2016, August 23). Cosmopolitan.bg. Retrieved November 24, 2018, from http://www.cosmopolitan.bg/po-sveta-/lindzi-loun-poshturia-iskaruskiia-prezident-putin.html.

Lyons, J. D. (2018). Donald Trump quotes about Putin show he doesn't care what you think about their relationship. Bustle. Retrieved November 24, 2018, from http://www.bustle.com.

Machin, D., \& van Leeuwen, T. (2003). Global schemas and local discourses in Cosmopolitan. Journal of Sociolinguistics, 7(4), 493-512.

Machin, D., \& van Leeuwen, T. (2008). Branding the self. In C. R. Caldas-Coulthard \& R. Iedema (Eds.), Identity trouble: Critical discourse and contested identities (pp. 43-57). London, UK: Palgrave Macmillan.

Mackintosh, E. (2017, January 13). Hungarian camerawoman sentenced for kicking, tripping refugees. CNN. Retrieved November 24, 2018, from http://www.cnn.com.

Mazzoleni, G., Stewart, J., \& Horsfield, B. (Eds.). (2003). The media and neo-populism: A contemporary comparative analysis. Westport, CT: Greenwood Publishing Group.

McCargo, D. (2016). Duterte's mediated populism. Contemporary Southeast Asia: A Journal of International and Strategic Affairs, 38(2), 185-190.

McConnaughy, C. M. (2013). The woman suffrage movement in America: A reassessment. New York: Cambridge University Press.

Media Research Center. (1996). Women's magazines: A liberal pipeline to soccer moms [executive summary]. Retrieved November 24, 2018, from http://www.mrc.org/special-reports/womens-magazines-liberal-pipeline-soccer-moms.

Mercury Publicity. (2018). The Balkans: Bulgaria: Cosmopolitan. Retrieved November 24, 2018, from http://www.mercury-publicity.com/balkans? lightbox=dataItem-jauysjjz. 
Midgley, D., \& Hutchins, C. (2015). Abramovich: The billionaire from nowhere. London: James Leasor Publishing.

Minutaglio, R. (2018, September 5). The intern who yelled ' $\mathrm{f}^{\star} \mathrm{ck}$ you' at Trump does not regret it. Cosmopolitan.com. Retrieved November 23, 2018, from http://www.cosmopolitan.com.

Mudde, C. (2000). In the name of the peasantry, the proletariat, and the people: Populisms in Eastern Europe. East European Politics and Societies, 15(1), 33-53.

Mudde, C. (2017). Politics at the fringes? Eastern Europe's populists, racists, and extremists. In A. Fagan \& P. Kopecky (Eds.), The Routledge handbook of East European politics (pp. 254-263). New York: Routledge.

Mulla, A. (2017). Broadcasting the Dharna: Mediating "contained" populism in contemporary Pakistan. International Journal of Communication, 11, 4181-4196.

Natalia Gurkova "paraded" with Putin. (2018). Elle.bg. Retrieved November 24, 2018, from http://www. elle.bg/novini-35/nataliia-gurkova-defilira-s-putin.html.

Oh, those beaches. (2015, May 22). Elle.bg. Retrieved November 24, 2018, from http://www.elle.bg/ puteshestviia/ah-tezi-plajove.html.

Ornella Muti sentenced for dining with Putin. (2015, February 25). Cosmopolitan.bg. Retrieved November 24, 2018, from http://www.cosmopolitan.bg/liubopitno/osudiha-ornela-muti-za-vecheria-s-putin.html.

Pan, Z., \& Kosicki, G. (1993). Framing analysis: An approach to news discourse. Political Communication, $10(1), 55-75$.

Parfitt, T. (2006, October 20). Putin praises sexual prowess of Israeli president. The Guardian. Retrieved November 24, 2018, from http://www.theguardian.com.

Peicheva, D., \& Raycheva, L. (2017). Framing political populism in contemporary media ecosystem. European Quarterly of Political Attitudes and Mentalities, 6(4), 1-13.

Pizhov, K. (2016a, November 11). The stars' private jets. Elle.bg. Retrieved November 24, 2018, from http:// www.elle.bg/istorii/chastnite-samoleti-na-zvezdite.html.

Pizhov, K. (2016b, November 10). Let's dress USA's naked First Lady! Elle.bg. Retrieved November 24, 2018, from http://www.elle.bg/stilut-na-zvezdite/da-oblechem-razgolenata-purva-dama-na-sasht. html.

Politicians and love. (2015, February 9). Elle.bg. Retrieved November 24, 2018, from http://www.elle.bg/ novini-35/politicite-i-liubovta.html.

Pool, W. C., \& Cureton, W. E. (1977). Westward I go free: The memoirs of William E. Cureton, Texas frontiersman. The Southwestern Historical Quarterly, 81(2), 155-190.

Roman and Darya: We are separating but staying friends. (2017, August 8). Cosmopolitan.bg. Retrieved November 24, 2018, from http://www.cosmopolitan.bg/zvezden-bulevard/abramovich-i-jukova-razdeliame-se-no-ostavame-priiateli.html.

Rupert Murdoch's ex vacationing with partner 27 years her junior. (2017, January 3). Elle.bg. Retrieved November 24, 2018, from http://www.elle.bg/novini-35/bishata-na-rupurt-murdok-na-vakanciia-s27-godini-po-mlad-ot-neia-partnor.html.

Rupnik, J. (2007). From democracy fatigue to populist backlash. Journal of Democracy, 18(4), 17-25.

Ruzza, C., \& Fella, S. (2011). Populism and the Italian right. Acta Politica, 46(2), 158-179.

Saarenmaa, L., \& Ruoho, I. (2014). Women's magazines in the Nordic style: Politics, politicians and the welfare state. European Journal of Communication, 29(3), 289-303.

SBB Media-Magazines. (2018). Elle. Retrieved November 24, 2018, from http://www.sbb.bg/en/pricesmagazines/elle-163.html.

Shafir, M. (2008). From historical to "dialectical" populism: The case of post-communist Romania. Canadian Slavonic Papers, 50(3-4), 425-470.

Simpson, P. A. (2016). Mobilizing meanings: Translocal identities of the far-right web. German Politics and Society, 34(4), 34-53. 
Slater, M. D. (1990). Processing social information in messages: Social group familiarity, fiction versus nonfiction, and subsequent beliefs. Communication Research, 17(3), 327-343.

Solomon, M. (1983). Stopping ERA: A Pyrrhic victory. Communication Quarterly, 31(2), 109-117.

Star IQ test. (2017, November 29). Elle.bg. Retrieved November 24, 2018, from http://www.elle.bg/novini-35/zvezden-iq-test-koi-izvestni-lichnosti-iznenadvat-s-visok-intelekt.html.

Sternadori, M. (2007). Sexy, tough, or inept: Portrayals of women terrorists in the news. Media Report to Women, 35(4), 14-22.

Sternadori, M., \& Hagseth, M. (2014). Fashionable feminism or feminist fashion? Media Report to Women, $42(4), 12-21$.

Tabakova, V. (2008). The Bulgarian media landscape. In G. Terzis (Ed.), European media governance: National and regional dimensions (pp. 303-313). Bristol, UK: Intellect.

The many trials of Silvio Berlusconi explained. (2014, May 9). BBC. Retrieved November 24, 2018, from http://www.bbc.com.

Thomas, R. E. (2018, October 5). Of course no one wanted to tell Trump he had toilet paper stuck to his shoe. Elle.com. Retrieved on November 23, 2018, from http://www.elle.com/culture/career-politics/ a23610074/of-course-no-one-wanted-to-tell-trump-he-had-toilet-paper-stuck-to-his-shoe/.

Tsang, A. (2016, November 10). Morning agenda: After Trump's election, what's next? The New York Times. Retrieved November 24, 2018, from http://www.nytimes.com.

Turovskii, R. F. (2010). How Russian governors are appointed: Inertia and radicalism in central policy. Russian Politics \& Law, 48(1), 58-79.

Vangelova, L. (2016a, September 15). Which billionaires lack a college degree? Elle.bg. Retrieved November 24, 2018, from http://www.elle.bg/kariera/koi-miliarderi-niamat-visshe-obrazovanie.html.

Vangelova, L. (2016b, October 26). 10 pieces of advice from Russian oligarch Roman Abramovich. Elle.bg. Retrieved November 24, 2018, from http://www.elle.bg/kariera/10-suveta-ot-ruskiia-oligarhabramovich-7323.html.

Vangelova, L. (2016c, July 19). Donald Trump's brightest quotes. Elle.bg. Retrieved November 24, 2018, from http://www.elle.bg/kariera/nai-iarkite-citati-na-donald-trump.html.

Van Herpen, M. H. (2013). Putinism: The slow rise of a radical right regime in Russia. London: Palgrave Macmillan.

Veth, K. M. (2014). The Berlusconization of post-Soviet football in Russia and the Ukraine: Money scores goals, goals win titles, and titles win popularity. Journal of Sport History, 41(1), 55-72.

Vladimir Putin inspired British brand. (2017, October 10). Elle.bg. Retrieved November 24, 2018, from http://www.elle.bg/tendencii/vladimir-putin-vduhnovi-britanski-brand.html.

Voskanian, T. (2017, October 12). Lagerfeld drew a cartoon of Merkel with Hitler. Elle.bg. Retrieved November 24, 2018, from http://www.elle.bg/novini-43/lagerfeld-narisuva-karikatura-na-merkelzaedno-s-hitler.html.

Vox Populist - The Voice of the Populist Party. (n.d.). In Facebook. Retrieved June 13, 2019, from https://www.facebook.com/pg/VOXPopulist/about/.

Weaver, D. (2007). Thoughts on agenda setting, framing, and priming. Journal of Communication, 57, $142-147$.

Wodak, R. (2015). The politics of fear: What right-wing populist discourses mean. London: Sage.

Woodward, C. V. (1938). Tom Watson and the Negro in agrarian politics. The Journal of Southern History, 4(1), 14-33.

Ytre-Arne, B. (2011). Women's magazines and the public sphere. European Journal of Communication, 26(3), 247-261.

Zúquete, J. P. (2008). The European extreme-right and Islam: New directions? Journal of Political Ideologies, 13(3), 321-344. 